Article

\title{
Engineering Education for Sustainable Development: Evaluation Criteria for Brazilian Context
}

\author{
Izabela Simon Rampasso ${ }^{1,2, *} \mathbb{D}$, Osvaldo L. G. Quelhas ${ }^{1}$, Rosley Anholon ${ }^{2}$, Marcio B. Pereira ${ }^{1}$, \\ Jocimar D. A. Miranda ${ }^{1}$ and Wenderson S. Alvarenga ${ }^{1}$ \\ 1 Laboratory of Technology, Business and Environment Management (LATEC), Federal Fluminense University, \\ Passo da Pátria Street, Niterói, Rio de Janeiro 24210-240, Brazil; osvaldoquelhas@id.uff.br (O.L.G.Q.); \\ marciobatista@terra.com.br (M.B.P.); jdam-17@hotmail.com (J.D.A.M.); \\ wendersonsant@hotmail.com (W.S.A.) \\ 2 School of Mechanical Engineering, University of Campinas, Mendeleyev Street, Campinas, \\ São Paulo 13083-970, Brazil; rosley@fem.unicamp.br \\ * Correspondence: izarampasso@gmail.com
}

Received: 19 April 2020; Accepted: 6 May 2020; Published: 12 May 2020

\begin{abstract}
Considering the increasing importance of sustainability in future professionals' education and the role played by engineers in society, this paper aims to analyze the key criteria that should be considered in models to evaluate the insertion level of sustainability into engineering education, considering the Brazilian context. For this, criteria reported in the literature were collected and evaluated by engineering professors. The respondents were asked to classify the criteria as "essential", "useful, but not essential", or "not necessary". Data collected were analyzed through Lawshe's method. From 15 criteria collected from the literature, 5 were not considered essential to evaluate engineering education for sustainable development (EESD), according to data analysis: C2 (establishment of global partnerships), C4 (encouraging students to volunteer through extracurricular activities), C9 (use of active learning approaches to problem solving to teach aspects related to sustainability), C10 (use of service-learning towards the local community for educational purposes) and C15 (use of sustainability concept in university installations). It was possible to verify that most of these criteria (C2, C4, C10, and C15) were not directly related to engineering curricula, being parallel activities. Regarding C9, active learning approaches can enhance attributes important for students in the context of sustainable development, but they are not goals of EESD. This research contributes to the development of evaluation models for engineering education in the Brazilian context and its findings can also be useful for studies in other countries. No similar study was found in the literature.
\end{abstract}

Keywords: sustainability; sustainable development; engineering education; EESD; Brazil

\section{Introduction}

Sustainable development has been debated in the literature for years [1-5]. Proper use of natural resources, the use of renewable sources of energy [6,7], and corporate social responsibility have been increasingly relevant for companies [8-10]. In this scenario, the publication of 17 Sustainable Development Goals (SDGs), in 2015, by the United Nations [11] can be considered a landmark, as highlighted by Martins et al. [12]. Among these goals, besides the relevance of organizations to enable sustainable development, educational system contribution for it is also emphasized $[13,14]$. The United Nations Educational, Scientific and Cultural Organization (UNESCO) [15] highlights that education for sustainable development (ESD)—considered within Quality Education (Goal 4) — has a key role to support the achievement of the other 16 goals. The need to develop knowledge and competences in students to enable them to act towards sustainable development is specified in Target 4.7 (from Goal 4) [13]. 
The reason for this, especially when considering higher education, is the opportunity to prepare future professionals to consider sustainability aspects in their work. In this sense, when the role of engineers for society is considered, the relevance of this preparation can be evidenced $[14,16,17]$.

According to UNESCO [15], Quelhas et al. [18], and Svanström et al. [19], the main skills to be developed in engineering undergraduate students towards ESD are integrated resolution, self-knowledge, critical thinking, collaboration, normative competence, and systemic thinking. According to several authors, these kinds of skills need to be developed through active learning methodologies $[16,20,21]$. These kinds of skills can be developed through active learning approaches, such as problem-based learning (PBL) [16].

Despite general insights and guidelines for sustainability's insertion into engineering education, country-level analysis is important to understand specific contexts. Takala and Korhonen-Yrjänheikki [22], analyzing Finnish engineering education, verified an alignment of it with sustainability aspects. However, there are still opportunities for improvement. Among them, the lack of integration of goals and strategies can be mentioned. In Leal Filho et al. [23], seven case studies related to education for sustainable development in Latvia, Syria, Brazil, the United Kingdom, Serbia, Spain, and South Africa were analyzed. Through these analyses, it was verified that there are still improvement opportunities in the analyzed cases and better integration between ESD and higher education institutions (HEIs) is required.

Focusing on the Brazilian reality, there are cases reported in the literature regarding sustainability insertion in higher education [24,25] and, more specifically, in engineering education [26]. However, there are several challenges to be overcome [14,27]. Additionally, most of the studies found in the literature focus on sustainable practices implementation into Brazilian HEIs [28-31], instead of ESD.

In this sense, more studies analyzing ESD in Brazilian HEIs are necessary and tools to measure it can be useful to guide these studies, as well as the establishment of ESD. Considering this need, Cronemberger de Araújo Góes and Magrini [32] proposed guidelines for the creation of a sustainability assessment tool (SAT) for the Brazilian reality. In the same line of the mentioned authors, our research aimed to analyze the key criteria that should be considered in models to evaluate the insertion level of sustainability into engineering education, considering the Brazilian context. In the next section, the criteria identified in the literature and used as a theoretical basis for this study are presented.

\section{Theoretical Background}

The literature has been showing several issues to be addressed in engineering education for sustainable development (EESD). One of the most relevant issues cited is the need for a transdisciplinary approach [22,33-35]. As argued by Tejedor et al. [17] and Shields et al. [36], more than addressing interfaces among disciplines, transdisciplinarity overcomes their boundaries and articulates different perspectives through a holistic approach.

The second criterion to be mentioned is the establishment of global partnerships. Lazzarini et al. [37] highlight the need to show students the global dimension of engineering education and the global social and environmental responsibility of their actions. In this sense, the establishment of institutional strategies of global partnerships [33] can be a useful means to reach education for sustainability service [38] and to enhance the search for sustainable development through the integration of countries' competences and knowledge [39]. Despite the benefits, challenges are faced for these types of partnerships, when increasing competition among HEIs is established [37].

Another issue related to institutional strategy is its alignment with sustainability insertion and top management support for this insertion. As argued by Iyer-Raniga and Andamon [40], the sustainability insertion in higher education needs to be performed strategically. In addition, these authors highlight that top management also needs to learn about sustainability for this concept to be effectively reached. Indeed, Holgaard et al. [38] and Rampasso et al. [27] emphasize that the lack of this support is considered a barrier for ESD. 
The importance of encouraging students to volunteer through extracurricular activities is also addressed. According to McCormick et al. [41], volunteer actions may enhance students' knowledge and understanding of social issues, which can impact their professional actions. Focusing on students who participate in Enactus-a non-profit international organization that engage students in social actions-Rampasso et al. [14] highlight the increased ability of these students to critically analyze ESD.

Another issue to be evaluated regarding EESD is the balanced focus among environmental, social, and economic aspects of sustainability. Edvardsson Björnberg et al. [42] mentioned the difficulty faced by the KTH Royal Institute of Technology (KTH) to address the social aspect in engineering education whereas environmental concepts were properly integrated into engineering programs. In Akeel et al. [43], the same difficulty is mentioned. Regarding sustainability aspects, the economic category is also mentioned in the literature as less considered than environmental issues in engineering education [42,43]. Raoufi et al. [44] highlight the importance of preparing engineering students to consider social, economic, and environmental aspects in their professional decisions. For this, the authors point out the need for teaching decision tools to support students.

A sixth criterion to be evaluated according to the literature is critical thinking development in students. As argued by Guerra [16], critical, systemic, and holistic thinking are required to enable students to insert sustainability aspects into their professional activities and continuously learn to improve their actions. McWhirter and Shealy [35] emphasize the role of active learning approaches, such as problem-based learning, to develop this critical thinking in students and make them consider sustainable development issues in their decisions. Other authors corroborate with this argument and add that this kind of teaching approach enhances systematic and holistic thinking, as well. Among the reasons for this compatibility is the transdisciplinary character of sustainability [16,17].

These arguments justify the need for active learning approaches to problem solving. Among these approaches, PBL is among the most cited. PBL is centered on students conducting activities within teams and needing to search for solutions to real-life problems. In this approach, students are responsible for their learning process and have to be proactive to acquire knowledge and solve proposed problems [16]. In this sense, it is easier to reach a transdisciplinary solution with this kind of approach $[16,17]$. Specific approaches resulting from active learning proposals can also be interesting. Ramanujan et al. [45] presented an approach to insert environmental sustainability into mechanical engineering courses through a guided discovery approach.

Another criterion relevant for EESD is the presence of discussions of issues related to values and ethics with students throughout the course. Biswas [46] points out that future engineers will encounter demands for ethical behavior concerned with the social and environmental impacts of their work. For Segalàs et al. [47], values and ethics are core competencies for engineering students to learn about and apply for concepts of sustainable development. Byrne et al. [48] emphasize the need for a curricular change for engineers to prioritize ethical behavior rather than exclusively meeting customers' demands without considering the negative consequences. An interesting manner to teach ethics and values for engineering students can be through service-learning.

Service-learning enables students to learn through actions toward the local community [17]. More than learning manners to create things as engineers, service-learning develops students as citizens, increasing their compassion; social skills, such as working within teams; and emotional intelligence [49].

Focusing on the technical aspects of engineering knowledge, another important issue to be addressed is the application of technical knowledge towards sustainability goals. Raoufi et al. [44] highlight the need to prepare students to perform life cycle assessment. In addition to life cycle assessment, Biswas [46] also presents other industrial ecology issues that can be used in EESD. Among them, eco-efficiency and cleaner production can be highlighted as complementary strategies; while cleaner production focuses on operational process improvements to reduce environmental negative impacts, eco-efficiency focuses on greater efficiency in value creation. 
Regarding social abilities, communication skills are important to enable students to work within multidisciplinary groups [16,46]. Shields et al. [36], however, highlighted that engineering students fail to present communication abilities. For Guerra [16], PBL is an approach able to develop these abilities in students. This approach is frequently mentioned in the literature.

Adequate and constantly updated teaching material that includes sustainability in the course is another criterion to be analyzed for EESD. In addition to a lack of materials for professors to properly provide transdisciplinary knowledge, the lack of constant updates in their content is a challenge when considering the dynamic character of sustainability-related concepts [50,51].

Despite the lack of proper didactic material, professors need to be prepared to support students learning in a sustainable development context. This is especially required because professors need to change their actions and acquire new abilities to work in this new reality [40]. Mulder [52] presents several comments of engineering professors that clearly show they do not understand the role engineers need to play towards sustainable development, which demonstrates the necessity of the mentioned training.

Finally, regarding university installations, there are several opportunities to use sustainability concepts. Among these opportunities, the efficiency in water use, ecologically correct buildings, energy efficiency, and appropriate waste management can be highlighted $[38,53]$.

From this literature overview, it was possible to establish Table 1.

Table 1. Criteria to evaluate engineering education for sustainable development (EESD).

\begin{tabular}{|c|c|c|}
\hline Code & Criteria & References \\
\hline $\mathrm{C} 1$ & Use of transdisciplinarity in teaching & {$[14,16,17,22,27,33,35,36,47,48,50,54-58]$} \\
\hline $\mathrm{C} 2$ & Establishment of global partnerships & {$[33,37-39]$} \\
\hline C3 & $\begin{array}{l}\text { Alignment between sustainability insertion and } \\
\text { institutional strategy, with top management support } \\
\text { for needed adjustments }\end{array}$ & {$[27,33,34,38,40,50]$} \\
\hline $\mathrm{C} 4$ & $\begin{array}{l}\text { Encouraging students to volunteer through } \\
\text { extracurricular activities }\end{array}$ & {$[14,33,41]$} \\
\hline C5 & $\begin{array}{l}\text { Balanced focus among environmental, social, and } \\
\text { economic aspects of sustainability }\end{array}$ & {$[27,42-44,46,48,50,56,57,59,60]$} \\
\hline C6 & $\begin{array}{c}\text { Development of critical thinking in students } \\
\text { throughout the course }\end{array}$ & {$[16,18,35,47,48,59]$} \\
\hline C7 & $\begin{array}{l}\text { Development of holistic and systemic thinking in } \\
\text { students throughout the course to enable them to } \\
\text { make decisions responsibly }\end{array}$ & {$[16-18,43,47,57,60,61]$} \\
\hline $\mathrm{C} 8$ & $\begin{array}{l}\text { Discussion of issues related to values and ethics with } \\
\text { students throughout the course }\end{array}$ & {$[18,46-48,55,60]$} \\
\hline C9 & $\begin{array}{l}\text { Use of active learning approaches to problem solving } \\
\text { to teach aspects related to sustainability }\end{array}$ & {$[16,17,33,35,45,56]$} \\
\hline $\mathrm{C} 10$ & $\begin{array}{l}\text { Use of service-learning towards the local community } \\
\text { for educational purposes }\end{array}$ & {$[17,33,49]$} \\
\hline C11 & $\begin{array}{c}\text { Constant discussion, throughout the course, of } \\
\text { industrial applications of technical knowledge for } \\
\text { sustainability (for example, life cycle assessment, } \\
\text { cleaner production, ecologically efficient strategies } \\
\text { for resources use, etc.) }\end{array}$ & {$[33,34,36,44,46,48,50,55,59,62,63]$} \\
\hline $\mathrm{C} 12$ & $\begin{array}{l}\text { Development of communication skills in students to } \\
\text { enable them to work within multidisciplinary groups }\end{array}$ & {$[16,36,43,46,48,57]$} \\
\hline $\mathrm{C} 13$ & $\begin{array}{c}\text { Availability of adequate and constantly updated } \\
\text { teaching material to include sustainability in the } \\
\text { course }\end{array}$ & {$[50,51]$} \\
\hline $\mathrm{C} 14$ & $\begin{array}{l}\text { Proper training of professors to insert sustainability } \\
\text { into their disciplines }\end{array}$ & {$[40,50,52]$} \\
\hline $\mathrm{C} 15$ & $\begin{array}{l}\text { Use of sustainability concept in university } \\
\text { installations }\end{array}$ & {$[14,38,53]$} \\
\hline
\end{tabular}




\section{Methodological Procedures}

In order to verify the criteria should be considered in models to evaluate the sustainability insertion level in engineering education, this research was developed in two stages: a search in the literature and survey data analysis. Figure 1 shows the steps followed in these stages.

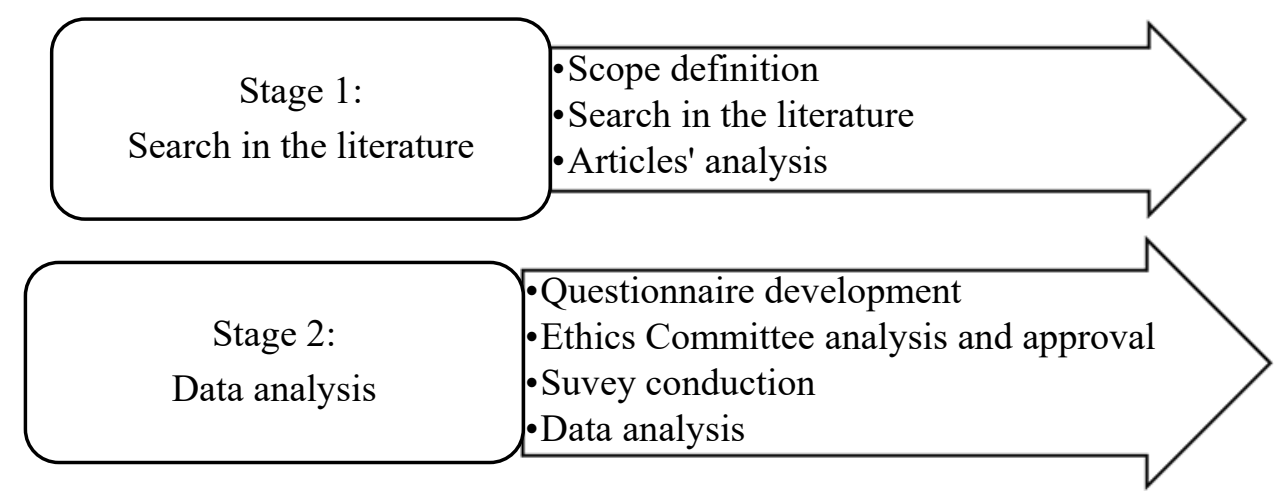

Figure 1. Steps followed in each research stage.

A search in the literature was conducted to collect the criteria to be analyzed. The strings "engineering education" and "sustainability"; "engineering education" and "sustainable development" in articles' abstracts were used to search for articles in Emerald Insight, Science Direct, and Taylor and Francis. Articles were analyzed and criteria pointed out as relevant for EESD were collected. Only articles from international journals were considered (proceeding were excluded from the sample). From this analysis, 15 criteria (presented in the theoretical background section) were identified and used to structure a questionnaire for a survey of engineering professors in Brazil experienced with sustainability issues. The survey was performed after approval from the university's ethics committee.

To verify which criteria collected in the literature were considered essential, according to engineering professors in Brazil, experts in the subject, Lawshe's method [64] was used. The aim of this method is to quantify consensus. Of course, when all respondents attribute "essential" for an item or no one does, the consensus is clear. However, for scenarios presenting divergencies, Lawshe's method enables the consensus quantification. There are two assumptions in this method: content validity starts to be perceived when at least $50 \%$ of experts attribute "essential" for the item; and the content validity degree increases according to the number of experts classifying the item as "essential" [64].

In this method, content validity ratio $\left(C V R=\frac{n_{e}-(N / 2)}{N / 2}\right)$ was used to identify the essential criteria. For this calculus, experts classified the criteria as "essential", "useful, but not essential", or "not necessary". The number of "essential" answers $\left(n_{e}\right)$ was used in the CVR calculation as well as the number of responses $(N)$. CVR value will be negative when less than half of respondents classify the item as "essential". Ayre and Scally [65] contributed to Lawshe's method calculating CVR critical values with exact binomial probabilities $\left(C V R=\frac{[(z \sqrt{N})+1]}{N}\right)$. It is important to emphasize that Ayre and Scally [65] state that their values and Lawshe's values for the critical number of experts are generally equal, validating Lawshe's method. After Lawshe's method analysis, the findings were compared with the literature. In the next section, the results from the analysis are presented.

\section{Results and Discussion}

The sample of this study was professors of engineering in Brazilian universities. A total of 35 professors answered the survey. Most of them had Ph.D. degrees. Regarding experience as professors, $51.43 \%$ had up to 10 years of experience; $40 \%$ had between 11 and 20 years of experience; and $8.57 \%$ had more than 20 years of experience. All respondents had experience related to sustainability, through research and/or teaching. 
The respondents were asked to evaluate criteria from the literature as "essential", "useful, but not essential", or "not necessary". As presented in the methodological procedures section, the number of "essential" answers were used to calculate $C V R$ values. Since 35 experts answered the survey, the $C V R$ critical value was 0.31 according to Lawshe [64] and 0.314, according to Ayre and Scally [65] calculus. This similarity is aligned with Ayre and Scally's [65] statement about the equality between their values and Lawshe's values for the critical number of experts. In another perspective, at least 23 respondents must attribute "essential" to the criterion [65]. The results for this sample are presented in Table 2. It is worth highlighting that Lawshe's [64] equation $\left(C V R=\frac{n_{e}-(N / 2)}{N / 2}\right)$ was used for the calculus.

Table 2. Sample analysis for Lawshe's method.

\begin{tabular}{ccc}
\hline Code & Number of “Essential” Answers & Content Validity Ratio (CVR) \\
\hline C1 & 30 & 0.714 \\
C2 & 15 & -0.143 \\
C3 & 30 & 0.714 \\
C4 & 16 & -0.086 \\
C5 & 29 & 0.657 \\
C6 & 34 & 0.943 \\
C7 & 33 & 0.886 \\
C8 & 34 & 0.943 \\
C9 & 20 & 0.143 \\
C10 & 12 & -0.314 \\
C11 & 27 & 0.543 \\
C12 & 27 & 0.543 \\
C13 & 24 & 0.371 \\
C14 & 25 & 0.429 \\
C15 & 22 & 0.257 \\
\hline
\end{tabular}

The criteria considered essential by the experts were: $\mathrm{C} 1$ (use of transdisciplinarity in teaching); C3 (alignment between sustainability insertion and institutional strategy, with top management support for needed adjustments); C5 (balanced focus among environmental, social, and economic aspects of sustainability); C6 (development of critical thinking in students throughout the course); C7 (development of holistic and systemic thinking in students throughout the course to enable them to make decisions responsibly); C8 (discussion of issues related to values and ethics with students throughout the course); C11 (constant discussion, throughout the course, of industrial applications of technical knowledge for sustainability (for example, life cycle assessment, cleaner production, ecologically efficient strategies for resources use, etc.)); C12 (development of communication skills in students to enable them to work within multidisciplinary groups); $\mathrm{C} 13$ (availability of adequate and constantly updated teaching material to include sustainability in the course); and C14 (proper training of professors to insert sustainability into their disciplines).

Regarding the criteria validated as essential by the experts, it is possible to verify that seven of them are directly related to the goals of EESD: use of transdisciplinarity in teaching (C1); balanced focus among environmental, social, and economic aspects of sustainability (C5); development of critical, holistic, and systemic thinking in students (C6 and C7); discussion of issues related to values and ethics (C8); discussion on industrial applications of technical knowledge for sustainability (C11); and development of communication skills in students to enable them to work within multidisciplinary groups (C12). It is possible to observe that all these criteria focus on enhancing students' knowledge and skills related to sustainable development and they may be integrated into engineering education classes.

The other three criteria (alignment between sustainability insertion and institutional strategy, with top management support for needed adjustments-C3; availability of adequate and constantly updated teaching material to include sustainability in the course- $\mathrm{C} 13$; and proper training of professors to insert sustainability into their disciplines-C14) are necessary to make the other seven validated criteria viable. 
As it is presented in Table 2, C2 (establishment of global partnerships), C4 (encouraging students to volunteer through extracurricular activities), C9 (use of active learning approaches to problem solving to teach aspects related to sustainability), C10 (use of service-learning towards the local community for educational purposes) and C15 (use of sustainability concept in university installations) did not receive enough "essential" answers to be considered essential criteria.

Analyzing these five criteria, it is possible to verify that $\mathrm{C} 2, \mathrm{C} 4, \mathrm{C} 10$, and $\mathrm{C} 15$ are not directly related to engineering curricula, being parallel activities. Regarding the establishment of global partnerships, despite its importance for students to integrate countries' competences and knowledge [39] and become aware of their role as global citizens, it may be a great challenge when globalization causes increasing competition among universities, distancing academics worldwide [37].

The encouragement of students to volunteer through extracurricular activities was not considered essential, too. Here it is worth emphasizing that this does not mean experts did not consider extracurricular activities important, but they do not consider them essential as a criterion for an evaluation model focused on engineering courses. Although this kind of activity may enhance students' knowledge and perception of social issues [41], experts do not consider this encouragement an essential role of HEIs.

A similar analysis can be addressed for the use of service-learning towards the local community for educational purposes. The benefits from it mentioned in the literature $[17,49]$ are not being judged, but the responsibility of engineering courses to make this bridge can be contested.

As mentioned in the literature $[38,53]$, the use of the sustainability concept in university installations presents several opportunities and can benefit the environment and society. However, it may not have a strong connection between HEIs' good practices and students' learning regarding sustainability. The engagement of students in activities to improve HEIs' practices related to sustainability may present better results than implemented practices themselves.

The exclusion of the use of active learning approaches to problem solving to teach aspects related to sustainability from the essential criteria list can be explained by the fact of these approaches being used as a possible means to achieve several attributes for students, such as critical thinking, systemic thinking, and communication skills, among others [16]. Thus, the use of these approaches can enhance these achievements, but they are not goals of EESD.

\section{Conclusions}

This article aimed to analyze the key criteria that should be considered in models to evaluate the insertion level of sustainability into engineering education, considering the Brazilian context. After a literature analysis, experts were asked about the relevance of each criterion identified as potentially essential for EESD programs. Data were analyzed with Lawshe's method. According to the sample, C2 (establishment of global partnerships), C4 (encouraging students to volunteer through extracurricular activities), C9 (use of active learning approaches to problem solving to teach aspects related to sustainability), C10 (use of service-learning towards the local community for educational purposes), and C15 (use of sustainability concept in university installations) were not considered essential criteria. Thus, from the 15 criteria collected, 10 were considered relevant to compose an evaluation model.

Regarding the criteria validated as essential by the experts, it is possible to verify that seven of them (C1-transdisciplinarity; $\mathrm{C} 5$ - balanced focus of sustainability; $\mathrm{C}$ - critical thinking; 7 -holistic and systemic thinking; $\mathrm{C} 8$ - values and ethics; $\mathrm{C} 11$-industrial applications of technical knowledge for sustainability; and C12-communication skills to work within multidisciplinary groups) focus on enhancing students' knowledge and skills related to sustainable development and they may be integrated into engineering education classes. The other three criteria (C3-strategy alignment; C13 - teaching material for sustainability teaching; and C14—professors' training) are necessary to make the other seven validated criteria viable. 
The five excluded criteria were not necessarily pointed out as unimportant, but they were considered not relevant to compose an evaluation model for EESD in the Brazilian context. It is possible to verify that most of these criteria $(\mathrm{C} 2, \mathrm{C} 4, \mathrm{C} 10$, and $\mathrm{C} 15)$ are not directly related to engineering curricula, being parallel activities. Regarding C9, active learning approaches can enhance attributes important for students in the context of sustainable development, but they are not goals of EESD. These analyses may explain the reason for excluding the five criteria from evaluation models. In this sense, the main contribution of this research was to collect relevant criteria from the literature to be used in evaluation models to assess EESD levels and identify, through experts' perception, those criteria that were essential to compose these models in the Brazilian reality.

Limitations of this study should be mentioned. This was exploratory research. Thus, findings are limited to the sample studied and the articles evaluated. However, it should be highlighted that criteria to evaluate EESD in the Brazilian reality are scarce in the literature and many of the items analyzed were obtained after a deep analysis of articles.

For future studies, there are several paths researchers can follow. Among them, it can be suggested: the establishment of an evaluation model from the essential criteria found, presenting indicators to measure the criteria; replication of this study in other countries and comparison with Brazilian experts; and case studies verifying the criteria's—considered essential in this study—application in engineering courses with different maturity levels.

Author Contributions: All the authors contributed equally to this paper, contributing to every part of the research. All authors have read and agreed to the published version of the manuscript.

Funding: This work was supported by the Conselho Nacional de Desenvolvimento Científico e Tecnológico (CNPq) under Grants 307536/2018-1 and 305442/2018-0. This study was also supported and partially financed by the Coordenação de Aperfeiçoamento de Pessoal de Nível Superior - Brasil (CAPES) - Finance Code 001, under process 88887.464433/2019-00.

Conflicts of Interest: The authors declare no conflict of interest.

\section{References}

1. Martins, V.W.B.; Rampasso, I.S.; Anholon, R.; Quelhas, O.L.G.; Leal Filho, W. Knowledge management in the context of sustainability: Literature review and opportunities for future research. J. Clean. Prod. 2019, 229, 489-500. [CrossRef]

2. Borges, M.L.; Anholon, R.; Cooper Ordoñez, R.E.; Quelhas, O.L.G.; Santa-Eulalia, L.; Leal Filho, W. Corporate Social Responsibility (CSR) practices developed by Brazilian companies: An exploratory study. Int. J. Sustain. Dev. World Ecol. 2018, 25, 509-517. [CrossRef]

3. Barata, J.; Quelhas, O.; Costa, H.; Gutierrez, R.; de Jesus Lameira, V.; Meiriño, M. Multi-Criteria Indicator for Sustainability Rating in Suppliers of the Oil and Gas Industries in Brazil. Sustainability 2014, 6, 1107-1128. [CrossRef]

4. Silva Rosa, A.A.; Abdala, E.C.; Cezarino, L.O. Sustainable practices and the relationship with suppliers in SSCM: A case study in wholesale. Braz. J. Oper. Prod. Manag. 2019, 16, 413-423. [CrossRef]

5. Camioto, F.D.C.; Mariano, E.B.; Rebelatto, D.A. Sustainability improvement opportunities in Brazilian sectors: Analysis of DEA slacks. Braz. J. Oper. Prod. Manag. 2017, 14, 363. [CrossRef]

6. Cozendey da Silva, H.N.; Prata, D.M.; Alves Lima, G.B.; Zotes, L.P.; Mattos, L.V. A techno-economic evaluation of the energy generation by proton exchange membrane fuel cell using biogas reforming. J. Clean. Prod. 2018, 200, 598-608. [CrossRef]

7. Rampasso, I.S.; Melo Filho, G.P.; Anholon, R.; de Araujo, R.A.; Alves Lima, G.B.; Perez Zotes, L.; Leal Filho, W. Challenges Presented in the Implementation of Sustainable Energy Management via ISO 50001:2011. Sustainability 2019, 11, 6321. [CrossRef]

8. Arruda, L.; de Jesus Lameira, V.; Quelhas, O.; Pereira, F. Sustainability in the Brazilian Heavy Construction Industry: An Analysis of Organizational Practices. Sustainability 2013, 5, 4312-4328. [CrossRef] 
9. Cazeri, G.T.; Anholon, R.; da Silva, D.; Cooper Ordoñez, R.E.; Gonçalves Quelhas, O.L.; Filho, W.L.; de Santa-Eulalia, L.A. An assessment of the integration between corporate social responsibility practices and management systems in Brazil aiming at sustainability in enterprises. J. Clean. Prod. 2018, 182, 746-754. [CrossRef]

10. Anholon, R.; Quelhas, O.L.G.; Leal Filho, W.; de Souza Pinto, J.; Feher, A. Assessing corporate social responsibility concepts used by a Brazilian manufacturer of airplanes: A case study at Embraer. J. Clean. Prod. 2016, 135, 740-749. [CrossRef]

11. UN. Sustainable Development Goals (SDGs). Available online: https://www.un.org/sustainabledevelopment/ sustainable-development-goals/ (accessed on 1 May 2019).

12. Martins, V.; Anholon, R.; Quelhas, O.L.G.; Filho, W. Sustainable Practices in Logistics Systems: An Overview of Companies in Brazil. Sustainability 2019, 11, 4140. [CrossRef]

13. UN. Global Indicator Framework for the Sustainable Development Goals and Targets of the 2030 Agenda for Sustainable Development. Available online: https://unstats.un.org/sdgs/indicators/ GlobalIndicatorFrameworkafter2019refinement_Eng.pdf (accessed on 4 June 2019).

14. Rampasso, I.S.; Siqueira, R.G.; Anholon, R.; Silva, D.; Quelhas, O.L.G.; Leal Filho, W.; Brandli, L.L. Some of the challenges in implementing Education for Sustainable Development: Perspectives from Brazilian engineering students. Int. J. Sustain. Dev. World Ecol. 2019, 26, 367-376. [CrossRef]

15. UNESCO. Education for Sustainable Development Goals Learning Objectives; United Nations Educational, Scientific and Cultural Organization: Paris, France, 2017.

16. Guerra, A. Integration of sustainability in engineering education. Int. J. Sustain. High. Educ. 2017, 18, 436-454. [CrossRef]

17. Tejedor, G.; Segalàs, J.; Rosas-Casals, M. Transdisciplinarity in higher education for sustainability: How discourses are approached in engineering education. J. Clean. Prod. 2018, 175, 29-37. [CrossRef]

18. Quelhas, O.L.G.; Lima, G.B.A.; Ludolf, N.V.-E.; Meiriño, M.J.; Abreu, C.; Anholon, R.; Vieira Neto, J.; Rodrigues, L.S.G. Engineering education and the development of competencies for sustainability. Int. J. Sustain. High. Educ. 2019, 20, 614-629. [CrossRef]

19. Svanström, M.; Sjöblom, J.; Segalàs, J.; Fröling, M. Improving engineering education for sustainable development using concept maps and multivariate data analysis. J. Clean. Prod. 2018, 198, 530-540. [CrossRef]

20. Huang, Z.; Peng, A.; Yang, T.; Deng, S.; He, Y. A Design-Based Learning Approach for Fostering Sustainability Competency in Engineering Education. Sustainability 2020, 12, 2958. [CrossRef]

21. Tirado-Morueta, R.; Sánchez-Herrera, R.; Márquez-Sánchez, M.A.; Mejías-Borrero, A.; Andujar-Márquez, J.M. Exploratory study of the acceptance of two individual practical classes with remote labs. Eur. J. Eng. Educ. 2018, 43, 278-295. [CrossRef]

22. Takala, A.; Korhonen-Yrjänheikki, K. A decade of Finnish engineering education for sustainable development. Int. J. Sustain. High. Educ. 2019, 20, 170-186. [CrossRef]

23. Leal Filho, W.; Raath, S.; Lazzarini, B.; Vargas, V.R.; de Souza, L.; Anholon, R.; Quelhas, O.L.G.; Haddad, R.; Klavins, M.; Orlovic, V.L. The role of transformation in learning and education for sustainability. J. Clean. Prod. 2018, 199, 286-295. [CrossRef]

24. Friman, M.; Schreiber, D.; Syrjänen, R.; Kokkonen, E.; Mutanen, A.; Salminen, J. Steering sustainable development in higher education-Outcomes from Brazil and Finland. J. Clean. Prod. 2018, 186, 364-372. [CrossRef]

25. Rodrigues, C.; Payne, P.G. Environmentalization of the physical education curriculum in Brazilian universities: Culturally comparative lessons from critical outdoor education in Australia. J. Adventure Educ. Outdoor Learn. 2017, 17, 18-37. [CrossRef]

26. Rampasso, I.S.; Anholon, R.; Silva, D.; Cooper Ordóñez, R.E.; Quelhas, O.L.G.; Santa-Eulalia, L.A. Developing in engineering students a critical analysis about sustainability in productive systems. Int. J. Sustain. High. Educ. 2019, 20, 229-244. [CrossRef]

27. Rampasso, I.S.; Anholon, R.; Silva, D.; Cooper Ordoñez, R.E.; Quelhas, O.L.G.; Leal Filho, W.; Santa-Eulália, L.A. An analysis of the difficulties associated to sustainability insertion in engineering education: Examples from HEIs in Brazil. J. Clean. Prod. 2018, 193, 363-371. [CrossRef] 
28. Rebelatto, B.G.; Lange Salvia, A.; Reginatto, G.; Daneli, R.C.; Brandli, L.L. Energy efficiency actions at a Brazilian university and their contribution to sustainable development Goal 7. Int. J. Sustain. High. Educ. 2019, 20, 842-855. [CrossRef]

29. Gustavo de Lima, R.; Lins, H.N.; Pfitscher, E.D.; Garcia, J.; Suni, A.; Salgueirinho Osório de Andrade Guerra, J.B.; Caroline Renata Delle, F. A sustainability evaluation framework for Science and Technology Institutes: An international comparative analysis. J. Clean. Prod. 2016, 125, 145-158. [CrossRef]

30. Vieira, K.R.O.; Battistelle, R.A.G.; Bezerra, B.S.; de Castro, R.; Jabbour, C.J.C.; Deus, R.M. An exploratory study of environmental practices in two Brazilian higher education institutions. J. Clean. Prod. 2018, 187, 940-949. [CrossRef]

31. Avila, L.V.; da Silveira, J.S.T.; Neto, E.d.R.; Baggio, D.K. Barriers, potentialities, and actions for implementation of sustainable energy procedures in Brazilian federal universities. Environ. Qual. Manag. 2020, 129-137. [CrossRef]

32. Cronemberger de Araújo Góes, H.; Magrini, A. Higher education institution sustainability assessment tools: Considerations on their use in Brazil. Int. J. Sustain. High. Educ. 2016, 17, 322-341. [CrossRef]

33. Tejedor, G.; Rosas-Casals, M.; Segalas, J. Patterns and trends in engineering education in sustainability. Int. J. Sustain. High. Educ. 2019, 20,360-377. [CrossRef]

34. Sivapalan, S.; Clifford, M.J.; Speight, S. Engineering education for sustainable development: Using online learning to support the new paradigms. Australas. J. Eng. Educ. 2017, 4952, 1-13. [CrossRef]

35. McWhirter, N.D.; Shealy, T. Teaching decision-making for sustainable infrastructure: A wind energy case study module. Int. J. Sustain. High. Educ. 2018, 19, 893-911. [CrossRef]

36. Shields, D.; Verga, F.; Andrea Blengini, G. Incorporating sustainability in engineering education. Int. J. Sustain. High. Educ. 2014, 15, 390-403. [CrossRef]

37. Lazzarini, B.; Pérez-Foguet, A.; Boni, A. Key characteristics of academics promoting Sustainable Human Development within engineering studies. J. Clean. Prod. 2018, 188, 237-252. [CrossRef]

38. Holgaard, J.E.; Hadgraft, R.; Kolmos, A.; Guerra, A. Strategies for education for sustainable developmentDanish and Australian perspectives. J. Clean. Prod. 2016, 112, 3479-3491. [CrossRef]

39. Mihelcic, J.R.; Paterson, K.G.; Phillips, L.D.; Zhang, Q.; Watkins, D.W.; Barkdoll, B.D.; Fuchs, V.J.; Fry, L.M.; Hokanson, D.R. Educating engineers in the sustainable futures model with a global perspective. Civ. Eng. Environ. Syst. 2008, 25, 255-263. [CrossRef]

40. Iyer-Raniga, U.; Andamon, M.M. Transformative learning: Innovating sustainability education in built environment. Int. J. Sustain. High. Educ. 2016, 17, 105-122. [CrossRef]

41. McCormick, M.; Bielefeldt, A.R.; Swan, C.W.; Paterson, K.G. Assessing students' motivation to engage in sustainable engineering. Int. J. Sustain. High. Educ. 2015, 16, 136-154. [CrossRef]

42. Edvardsson Björnberg, K.; Skogh, I.-B.; Strömberg, E. Integrating social sustainability in engineering education at the KTH Royal Institute of Technology. Int. J. Sustain. High. Educ. 2015, 16, 639-649. [CrossRef]

43. Akeel, U.U.; Bell, S.J.; Mitchell, J.E. Assessing the sustainability content of the Nigerian engineering curriculum. Int. J. Sustain. High. Educ. 2019, 20, 590-613. [CrossRef]

44. Raoufi, K.; Park, K.; Hasan Khan, M.T.; Haapala, K.R.; Psenka, C.E.; Jackson, K.L.; Okudan Kremer, G.E.; Kim, K.-Y. A cyberlearning platform for enhancing undergraduate engineering education in sustainable product design. J. Clean. Prod. 2019, 211, 730-741. [CrossRef]

45. Ramanujan, D.; Zhou, N.; Ramani, K. Integrating environmental sustainability in undergraduate mechanical engineering courses using guided discovery instruction. J. Clean. Prod. 2019, 207, 190-203. [CrossRef]

46. Biswas, W.K. The importance of industrial ecology in engineering education for sustainable development. Int. J. Sustain. High. Educ. 2012, 13, 119-132. [CrossRef]

47. Segalàs, J.; Mulder, K.F.; Ferrer-Balas, D. What do EESD “experts” think sustainability is? Which pedagogy is suitable to learn it? Int. J. Sustain. High. Educ. 2012, 13, 293-304. [CrossRef]

48. Byrne, E.P.; Desha, C.J.; Fitzpatrick, J.J.; "Charlie" Hargroves, K. Exploring sustainability themes in engineering accreditation and curricula. Int. J. Sustain. High. Educ. 2013, 14, 384-403. [CrossRef]

49. Birzer, C.H.; Hamilton, J. Humanitarian engineering education fieldwork and the risk of doing more harm than good. Australas. J. Eng. Educ. 2019, 24, 51-60. [CrossRef]

50. Rampasso, I.S.; Anholon, R.; Silva, D.; Cooper Ordoñez, R.E.; Santa-Eulalia, L.A.; Quelhas, O.L.G.; Leal Filho, W.; Granada Aguirre, L.F. Analysis of the perception of engineering students regarding sustainability. J. Clean. Prod. 2019, 233, 461-467. [CrossRef] 
51. Fenner, R.A.; Ainger, C.M.; Cruickshank, H.J.; Guthrie, P.M. Embedding sustainable development at Cambridge University Engineering Department. Int. J. Sustain. High. Educ. 2005, 6, 229-241. [CrossRef]

52. Mulder, K.F. Strategic competences for concrete action towards sustainability: An oxymoron? Engineering education for a sustainable future. Renew. Sustain. Energy Rev. 2017, 68, 1106-1111. [CrossRef]

53. Moura, M.M.C.; Frankenberger, F.; Tortato, U. Sustainability in Brazilian HEI: Practices overview. Int. J. Sustain. High. Educ. 2019, 20, 832-841. [CrossRef]

54. Paten, C.J.K.; Palousis, N.; Hargroves, K.; Smith, M. Engineering sustainable solutions program. Int. J. Sustain. High. Educ. 2005, 6, 265-277. [CrossRef]

55. Fokkema, J.; Jansen, L.; Mulder, K. Sustainability: Necessity for a prosperous society. Int. J. Sustain. High. Educ. 2005, 6, 219-228. [CrossRef]

56. Sivapalan, S. Sustainability, blended learning and the undergraduate communication skills classroom: Negotiating engineering undergraduates' expectations and perceptions. Horizon 2017, 25, 7-23. [CrossRef]

57. Hanning, A.; Priem Abelsson, A.; Lundqvist, U.; Svanström, M. Are we educating engineers for sustainability? Int. J. Sustain. High. Educ. 2012, 13, 305-320. [CrossRef]

58. Bryce, P.; Johnston, S.; Yasukawa, K. Implementing a program in sustainability for engineers at University of Technology, Sydney. Int. J. Sustain. High. Educ. 2004, 5, 267-277. [CrossRef]

59. Riley, D.R.; Thatcher, C.E.; Workman, E.A. Developing and applying green building technology in an indigenous community. Int. J. Sustain. High. Educ. 2006, 7, 142-157. [CrossRef]

60. El-Zein, A.; Airey, D.; Bowden, P.; Clarkeburn, H. Sustainability and ethics as decision-making paradigms in engineering curricula. Int. J. Sustain. High. Educ. 2008, 9, 170-182. [CrossRef]

61. Nowotny, J.; Dodson, J.; Fiechter, S.; Gür, T.M.; Kennedy, B.; Macyk, W.; Bak, T.; Sigmund, W.; Yamawaki, M.; Rahman, K.A. Towards global sustainability: Education on environmentally clean energy technologies. Renew. Sustain. Energy Rev. 2018, 81, 2541-2551. [CrossRef]

62. Sharma, B.; Steward, B.; Ong, S.K.; Miguez, F.E. Evaluation of teaching approach and student learning in a multidisciplinary sustainable engineering course. J. Clean. Prod. 2017, 142, 4032-4040. [CrossRef]

63. Maeght, F.; Rasolomampionona, D.D.; Cresson, P.Y.; Favier, P. Wireless supervision on a photovoltaic recharging station. COMPEL Int. J. Comput. Math. Electr. Electron. Eng. 2013, 32, 192-205. [CrossRef]

64. Lawshe, C.H. A quantitative approach to content validity. Pers. Psychol. 1975, 28, 563-575. [CrossRef]

65. Ayre, C.; Scally, A.J. Critical Values for Lawshe's Content Validity Ratio. Meas. Eval. Couns. Dev. 2014, 47, 79-86. [CrossRef]

(C) 2020 by the authors. Licensee MDPI, Basel, Switzerland. This article is an open access article distributed under the terms and conditions of the Creative Commons Attribution (CC BY) license (http://creativecommons.org/licenses/by/4.0/). 